\title{
Environmental Drivers Controlling Bacterial and Archaeal Abundance in the Sediments of a Mediterranean Lagoon Ecosystem
}

\author{
Claudia Pala ${ }^{1,2,3} \cdot$ Massimiliano Molari $^{2,3} \cdot$ Daniele Nizzoli $^{1} \cdot$ Marco Bartoli $^{1} \cdot$ Pierluigi Viaroli $^{1} \cdot$ Elena Manini $^{2}$
}

Received: 13 November 2017 / Accepted: 27 April 2018 / Published online: 15 May 2018

(c) The Author(s) 2018

\begin{abstract}
The environmental factors controlling the abundance of Bacteria and Archaea in lagoon ecosystems are poorly understood. Here, an integrated physico-chemical, biogeochemical, and microbiological survey was applied in the Sacca di Goro lagoon (Po River Delta, Italy) to investigate the variation of bacterial and archaeal abundance, as assessed by Fluorescence In Situ Hybridization, along winter and summer environmental gradients. We hypothesised that bacterial and archaeal cells respond differentially to physico-chemical parameters of the sediment, which can be manifested in variations of total cells number. Our results suggest that Archaea are an important component of microbial communities (up to 20\%) and they are also quite constant along the sediment depth investigated, while Bacteria tend to decrease in the subsurface sediments. The abiotic (i.e. temperature, ammonium, $\mathrm{pH}$ ) and trophic parameters (i.e. chlorophyll $a$ ) explain differentially the variations of bacterial and archaeal distribution, and raise interesting questions about the ecological significance of the microbial composition in this area.
\end{abstract}

\section{Introduction}

The distribution of Bacteria in marine sediments have been extensively investigated [e.g. 9, 13, 19, 31, 33, 44, 57] and a variety of environmental factors have been reported to influence their abundance, such as sediment depth [20], salinity [47], phosphorus [27], organic matter [26], and $\mathrm{pH}$ [23]. Only recently, the role of Archaea in biogeochemical processes started to be elucidated, showing that they are involved in organic matter transformation such as methanogenesis [18], anaerobic methane oxidation (AMO, [8]), protein degradation [25], and aerobic ammonium oxidation [22]. Thus, only few studies quantified the abundance of

Electronic supplementary material The online version of this article (https://doi.org/10.1007/s00284-018-1503-3) contains supplementary material, which is available to authorized users.

Claudia Pala

cpala@mpi-bremen.de

1 Department of Chemistry, Life Sciences and Environmental Sustainability, University of Parma, Parma, Italy

2 Institute for Marine Science - ISMAR, National Research Council of Italy - CNR, Ancona, Italy

3 Max Planck Institute for Marine Microbiology, Celsiusstrasse 1, 28359 Bremen, Germany
Archaea in marine sediments, and investigated their variation with changes of environmental settings. These studies identified factors such as sediment depth, salinity, temperature, and food supply as the main archaeal environmental constrainers $[15,16,20,30]$.

Even less is known about the distribution of benthic Bacteria and Archaea in response to changes of environmental settings in aquatic transitional ecosystems, such as lagoons. Transitional ecosystems are generally characterised by strong physico-chemical gradients (i.e. temperature, salinity, nitrogen, $\mathrm{pH}$, and organic matter), which make these systems highly unstable and often subject them to unpredictable fluctuating conditions $[51,53]$. They typically behave as sinks for organic carbon [39], and the export of accumulated detritus towards higher trophic levels is mainly mediated by the functioning of the benthic microbial loop [26]. In these ecosystems, microbes control the flux of $\mathrm{C}$ and $\mathrm{N}$ to the atmosphere and within the trophic webs [5]. For a better understanding of the functioning of lagoons, and how human pressure can impact this ecosystem, it is important to clarify how environmental factors can shape microbial communities.

The Sacca di Goro (Italy) is a Mediterranean lagoon (Fig. 1) located in the southern part of the Po River Delta. As common feature of coastal lagoons, the Sacca di Goro is a transitional area characterised by shallow waters, reduced 


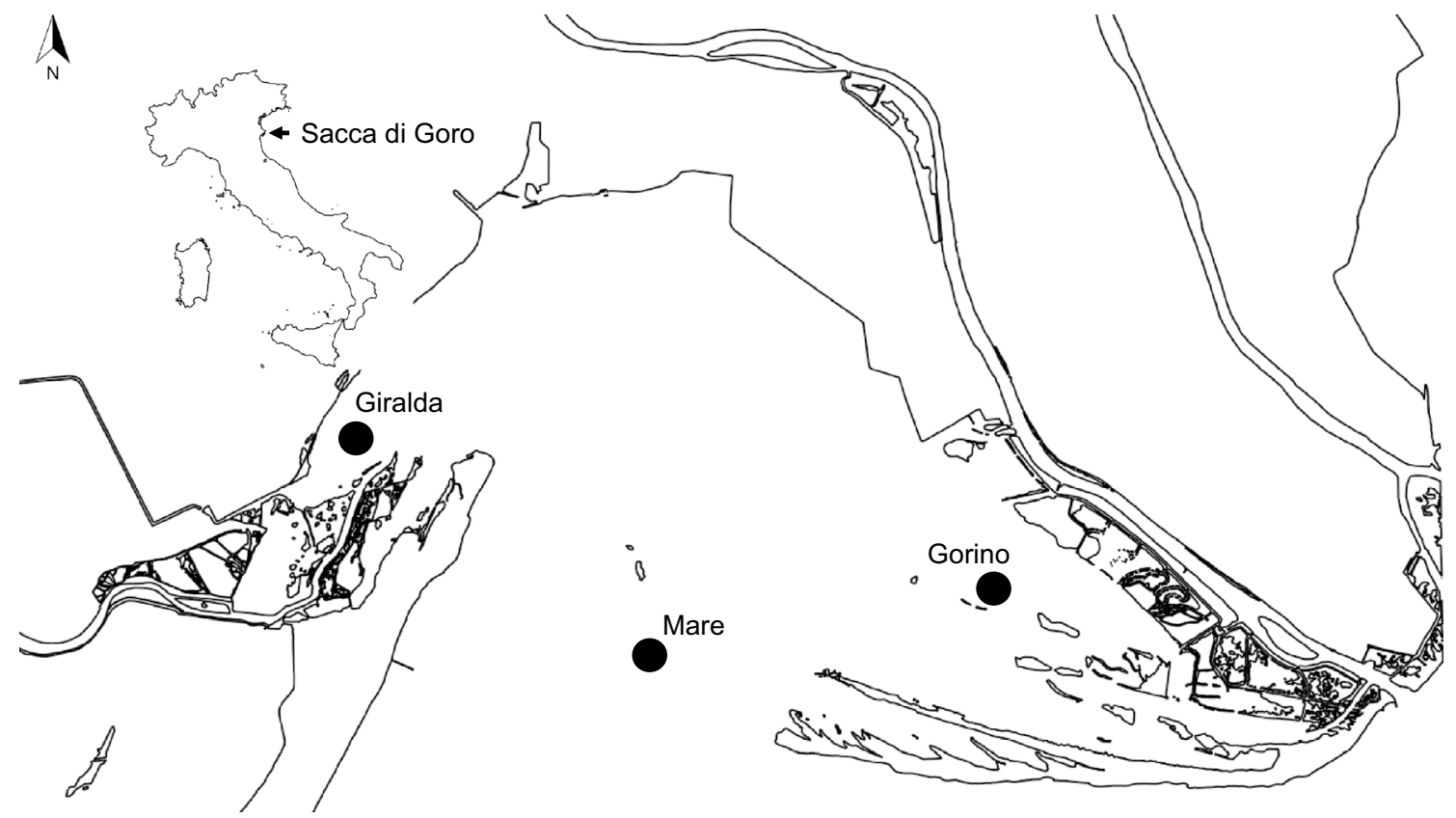

Fig. 1 The sampling area, Sacca di Goro Lagoon $\left(44.78-44.83^{\circ} \mathrm{N}, 2.25-12.33^{\circ} \mathrm{E}\right)$, and the three sampling sites Giralda, Gorino, and Mare

hydrodynamics, high productivity, and high sedimentation rates [53]. It is, therefore, sensitive to the phenomena of evaporation and precipitation, which, together with tidal currents, cause rapid changes in the chemical and physical properties, i.e. strong fluctuations in oxygen and sulphide concentrations [51]. The lagoon is also subjected to high anthropogenic pressures, receiving inputs of nutrients derived from organic and inorganic effluents of urban sewage. Furthermore, the Sacca di Goro is intensively exploited through farming of bivalves. All these factors alter the natural processes of the ecosystem causing eutrophication and dystrophy [54]. For this reason, this site is an ideal, natural laboratory to investigate the effects of strong environmental changes on bacterial and archaeal abundance and distribution. This lagoon has been well characterised from a biogeochemical point of view [51-54], but so far only few works have studied its microbiology. Manini et al. in 2003 [26] analysed the total microbial community, while Danovaro and Pusceddu in 2007 [13] provided information about bacterial and archaeal community structure using FISH and bacterial composition using ARISA. Both studies focused on the surficial sediments and only in one station of Sacca di Goro.

In this work, we have quantified the abundance of benthic Bacteria and Archaea along spatial and temporal environmental gradients of the Sacca di Goro lagoon via Fluorescence In Situ Hybridization. Alongside, we determined several environmental parameters to correlate with the observed cells number, aiming to identify community drivers. We found that differences in bacterial and archaeal abundance are correlated with physico-chemical parameters of the sediment and water/sediment interface. Additionally, we compared surface and subsurface sediment communities in terms of Bacteria versus Archaea dominance, and revealed a shift in microbial community composition with sediment depth towards higher archaeal abundance.

\section{Materials and Methods}

\section{Site and Sampling Description}

The study was carried out in the Sacca di Goro (Fig. 1), a semi-enclosed coastal lagoon of approximately triangular shape with a surface area of $26 \mathrm{~km}^{2}$ and an average depth of $1.5 \mathrm{~m}$. Samplings were carried out during two distinct periods of the year: spring/summer (June 2011) and winter (February 2012) using a hand-operated motorboat. We chose three sampling sites in the lagoon named, Giralda, Gorino, and Mare (Fig. 1). They were selected according to predetermined concentration of ammonium, dissolved oxygen, salinity, temperature, and $\mathrm{pH}$, i.e. representing sites along environmental gradients [52]. The station Giralda is characterised by silt-clay sediment, low salinity, and low hydrodynamics. Gorino is characterised by muddy sediment, and the presence of macroalgae during the summer that often caused anoxia and a local dystrophic crisis. Mare is closest to the Adriatic Sea and is thus characterised by sandy sediment and high salinity. At each site, sediment cores (transparent plexiglas liners of $8 \mathrm{~cm}$ diameter and $30 \mathrm{~cm}$ height) were 
collected in triplicates. The sediment was sliced into three different layers $(0-0.5 \mathrm{~cm}, 0.5-2 \mathrm{~cm}, 2-5 \mathrm{~cm})$ and kept separately at $4{ }^{\circ} \mathrm{C}$ until analysis.

The overlying water and upper layers of the sediment were tested for physico-chemical parameters. The overlying water $(100 \mathrm{ml})$ was immediately filtered $(0.7 \mu \mathrm{m} \mathrm{GF} / \mathrm{F})$ and stored at $4{ }^{\circ} \mathrm{C}$ until analysis. Within $24 \mathrm{~h}$ after collection, water samples were analysed for ammonium, nitrite, and nitrate concentrations.

\section{Environmental Parameters}

Salinity, temperature, $\mathrm{pH}$, dissolved oxygen, and redox potential (Eh) were measured in situ using a multiparametric probe (YSI Instruments, Yellow Springs, OH USA, model 556). Data points were collected from the overlying water in the core down to ca. $5 \mathrm{~cm}$ sediment depth. Ammonium, nitrite, and nitrate were determined in the overlying water.

Ammonium was determined spectrophotometrically using salicylate and hypochlorite in the presence of sodium nitroprusside [10]. Nitrite was determined spectrophotometrically after diazotisation reaction. Nitrate was determined spectrophotometrically after cadmium reduction of nitrate to nitrite [4], followed by the nitrite determination protocol.

\section{Biochemical Composition of the Sedimentary Organic Matter}

Total protein (PRT), carbohydrate (CHO), lipid (LIP), and chlorophyll $a$ (CHLA) were determined according to Danovaro [14]. Concentrations were calculated using standard curves and normalised to sediment dry weight after desiccation $\left(60^{\circ} \mathrm{C}, 24 \mathrm{~h}\right)$. Protein, carbohydrate, and lipid concentrations were converted into $\mathrm{C}$ equivalents using the conver-

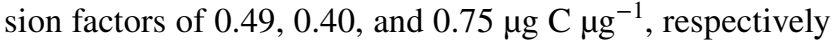
[17]. Biopolymeric organic C (BPC) was calculated as the sum of the $\mathrm{C}$ equivalents of protein, carbohydrate, and lipid, and this was used as a proxy for the available trophic resources [40].

\section{Fluorescence In Situ Hybridization (FISH) and Total Microbial Cells Number}

The microbial community structure was investigated using Fluorescence In Situ Hybridisation (FISH) [3]. Oligonucleotide probes labelled with a $\mathrm{Cy} 3$ fluorochrome at the $5^{\prime}$ end were purchased from Biomers (Biomers.net, Germany). We used universal probes for Bacteria (EUB338: 5'-GCT GCCTCCCGTAGGAGT-3' [2]; EUB338II: 5'-GCAGCC ACCCGTAGGTGT-3' [12]; EUB338III: 5'-GTCGCCACC CGTAGGTGT-3' [12]), for Archaea (Archaea915: 5'-GTG CTCCCCCGCCAATTCCT-3' [46]), and a negative control probe for non-specific binding (NONEUB: 5'-ACTCCT
ACGGGAGGCAGC-3' [55]) with $35 \%$ of formamide concentration in the hybridisation buffer. Hybridisations and microscopy counts of hybridised and DAPI (4,6-diamidino-2-phenylindole)-stained cells were performed as previously described [37, 38], (see Supplementary Materials for details).

The counting was performed with an epifluorescence microscope (Zeiss Axioskop 2) and the following filter sets: DAPI: Ex $359 \mathrm{~nm}$ and Em $441 \mathrm{~nm}$ : Cy3: Ex $546 \mathrm{~nm}$ and Em $575 \mathrm{~nm}$. Randomly, 20 fields of view were counted over the entire area of the filter for a total number of cells higher than 700 per filter piece.

\section{Statistical Analysis}

Principal component analysis (PCA) was performed to highlight differences in environmental settings among different sites, layers, and sampling time. Normality and homoscedasticity of data were examined, and, when required, data were transformed (e.g. $Z$ scoring, square root) and newly tested. The spatial variability of the bacterial and archaeal abundance and relative abundance, expressed as a percentage of total cells, were investigated using univariate analysis of variance (ANOVA). Tukey post hoc comparison tests $(\alpha=0.05)$ were applied when significant differences were encountered to identify the presence of patterns. In case the assumptions for an ANOVA were not met, Kruskal-Wallis test and post hoc Dunn test were performed. For testing the effect of space ("Site" and sediment "Layer") and time ("Season") on variations observed in bacterial and archaeal abundance, multifactorial ANOVA analyses were performed based on a three factors design with Layer nested in Site. Linear regression (LR) analysis was performed to investigate which environmental variable or set of variables could better explain the patterns in bacterial and archaeal abundance. Prior to the analyses, the explanatory environmental variables were transformed (i.e. $Z$ scoring) and diagnosed for collinearity based on the variance inflation factor (VIF). Only variables with VIF $<5$ were used in regression analysis (i.e. CHLA, BPC, pH, T, ammonium). Additionally, variation partitioning (VP) allowed to identify how much of the variation in bacterial and archaeal abundance was explained by the significant contribution of the explanatory variables returned by LR. All statistical analyses were performed in R (version 3.3.0 [41]) using packages vegan [36], usdm [34], and ggplots2 [56]. All results are represented in average values with standard deviation $( \pm)$. 


\section{Results}

\section{Physico-chemical Parameters}

Mare located closest to the Adriatic sea, had the highest salinity values (25\%o in summer and $29 \%$ winter), temperature was lower in summer $\left(23^{\circ} \mathrm{C}\right)$ and higher in winter $\left(13{ }^{\circ} \mathrm{C}\right)$, and the redox potential $(\mathrm{Eh})$ value was the most positive $(+398 \mathrm{mV})$ of all stations during winter. The $\mathrm{pH}$ value was 7.8. Dissolved oxygen (DO) did not show significant differences among the sampling stations, but was generally higher in winter than in summer (Tables 1,2). Giralda is located closest to the river mouth and had the lowest salinity $(5 \%)$. The highest and lowest values for water temperature were also recorded here, with $27.8^{\circ} \mathrm{C}$ in summer and $7.8^{\circ} \mathrm{C}$ in winter. Among the three stations Giralda showed highest nitrate, nitrite, and ammonium concentrations in winter $(125,5$, and $80 \mu \mathrm{M}$, respectively) and in summer $(48,3$, and $48 \mu \mathrm{M}$, respectively). At Giralda, the lowest $\mathrm{pH}$ values were measured, 7.2 during summer. At all other stations $\mathrm{pH}$ values were higher, especially during the winter, with highest $\mathrm{pH}$ value (8.3) recorded at Gorino (Tables 1, 2). Gorino, as the intermediate station between the Po river delta and the sea, showed intermediate concentrations of nitrate, nitrite, and ammonium during summer $(2.2,0.6$, and $9 \mu \mathrm{M}$, respectively) and winter (30, 1, and $15 \mu \mathrm{M}$, respectively; Table 1).

The redox potential (Eh) at Giralda and Gorino was determined down to $5 \mathrm{~cm}$ of the sediment. During summer, Eh values were positive at the surface ( +94.3 for Giralda, and +106.4 for Gorino). At layer $2(0.5-2 \mathrm{~cm})$, the sediment became chemically reduced with Eh values of -172.4 , and $-80.1 \mathrm{mV}$. Layer $3(2-5 \mathrm{~cm})$ had the most reduced conditions $(-179.9$, and -172.8$)$. In winter, the Eh values in the deeper parts of the sediment stayed positive at Giralda $(+121$ at layer 3$)$, but were strongly reduced at Gorino (-248 at layer 3; Table 2).
Table $2 \mathrm{pH}$ and Eh measurements in the three sediment layers of Mare, Gorino, and Giralda during summer and winter

\begin{tabular}{|c|c|c|c|c|}
\hline Season & Station & Layer & $\mathrm{pH}$ & Eh $(\mathrm{mV})$ \\
\hline \multirow[t]{8}{*}{ Summer } & \multirow[t]{2}{*}{ Mare } & 1 & 7.8 & 205.3 \\
\hline & & 3 & 7.9 & 195.3 \\
\hline & \multirow[t]{3}{*}{ Gorino } & 1 & 8.2 & 106.4 \\
\hline & & 2 & 7.5 & -80.1 \\
\hline & & 3 & 7.6 & -172.8 \\
\hline & \multirow[t]{3}{*}{ Giralda } & 1 & 7.5 & 94.3 \\
\hline & & 2 & 7.3 & -172.4 \\
\hline & & 3 & 7.2 & -179.9 \\
\hline \multirow[t]{9}{*}{ Winter } & \multirow[t]{3}{*}{ Mare } & 1 & 7.5 & 398 \\
\hline & & 2 & nd & nd \\
\hline & & 3 & nd & nd \\
\hline & \multirow[t]{3}{*}{ Gorino } & 1 & 8.3 & 107 \\
\hline & & 2 & 8 & 22 \\
\hline & & 3 & 7.9 & -248 \\
\hline & \multirow[t]{3}{*}{ Giralda } & 1 & 7.8 & 198 \\
\hline & & 2 & 7.7 & 182 \\
\hline & & 3 & 7.7 & 121 \\
\hline
\end{tabular}

Layer $1=0-0.5 \mathrm{~cm}$, layer $2=0.5-2 \mathrm{~cm}$, layer $3=2-5 \mathrm{~cm}$

$n d$ not detected

\section{Organic Matter Composition}

At Giralda, the sediment surface contained more organic matter than the deeper layers, both in summer and winter $\left(10.0 \pm 1.1 \mathrm{mg} \mathrm{C} \mathrm{g}^{-1}\right.$ at the surface, and $7.2 \pm 0.9 \mathrm{mg} \mathrm{C} \mathrm{g}^{-1}$ in layer 3). At Gorino, this trend was reversed, especially in winter, ranging from $5.6 \pm 0.6 \mathrm{mg} \mathrm{C} \mathrm{g}^{-1}$ at the surface to $10.8 \pm 1.4 \mathrm{mg} \mathrm{C} \mathrm{g}^{-1}$ at layer 3. Mare showed the lowest values of organic matter among the three stations, but the surface layer was again more enriched in organic matter than the deeper layers, especially in winter, ranging from $1.6 \pm 0.3 \mathrm{mg} \mathrm{C} \mathrm{g}^{-1}$ at the surface to $0.5 \pm 0.02 \mathrm{mg} \mathrm{C} \mathrm{g}^{-1}$ at layer 3, Fig. S1. The analysis of the composition of sedimentary organic matter (OM) showed that the dominant fraction was composed of total protein (PRT), on average 53\%. Furthermore, lipids (LIP) made up 26\% and
Table 1 Physico-chemical parameters in the overlaying water of Mare, Gorino, and Giralda during summer and winter

\begin{tabular}{lllllllll}
\hline Season & Station & Depth $(\mathrm{m})$ & $T\left({ }^{\circ} \mathrm{C}\right)$ & Salinity $(\%)$ & DO $(\%)$ & $\begin{array}{l}\text { Ammo- } \\
\text { nium } \\
(\mu \mathrm{M})\end{array}$ & Nitrite $(\mu \mathrm{M})$ & Nitrate $(\mu \mathrm{M})$ \\
\hline \multirow{2}{*}{ Summer } & Mare & 1.5 & 23.3 & 25 & 82 & 12 & 3 & 7 \\
& Gorino & 0.9 & 27.3 & 18.6 & 80 & 9 & 0.6 & 2.2 \\
& Giralda & 0.5 & 27.8 & 5 & 70 & 48 & 3 & 48 \\
\multirow{5}{*}{ Winter } & Mare & 1.5 & 13 & 29 & 127 & 7.5 & 2.9 & 192 \\
& Gorino & 0.9 & 8 & 24 & 89 & 15 & 1 & 30 \\
& Giralda & 0.5 & 7.8 & 9 & 94 & 80 & 5 & 125 \\
\hline
\end{tabular}


carbohydrates (CHO) $22 \%$ of the total organic matter. Biopolymeric carbon (BPC) was highest at Giralda, both in summer and winter, and lowest at Mare (Fig. S1).

Chlorophyll $a$ (CHLA) concentrations were highest at the surface sediment of Gorino in winter $\left(8.2 \pm 2.4 \mu \mathrm{g} \mathrm{g}^{-1}\right)$. Both at Gorino and Giralda, the chlorophyll $a$ was higher in winter than in summer. Mare had the lowest chlorophyll $a$ concentrations compared to the other stations, with higher values of $0.6 \pm 0.1 \mu \mathrm{g} \mathrm{g}^{-1}$ at the surface in summer than winter. In all stations, chlorophyll $a$ concentrations decreased with sediment depth (Fig. S1).

\section{Bacterial and Archaeal Abundance}

In this study, we applied Fluorescence In Situ Hybridization (FISH) to enumerate the abundance of Bacteria and Archaea cells in sediments of the Sacca di Goro lagoon. On average, the sum of bacterial and archaeal abundance relative to DAPI-stained cells ranged between $51 \pm 8 \%$ and $70 \pm 10 \%$ in summer and winter, respectively, (Fig. 2a, b). Bacterial and archaeal cells number were on average higher in summer than in winter (ANOVA, $P<0.001$ ). During both seasons,

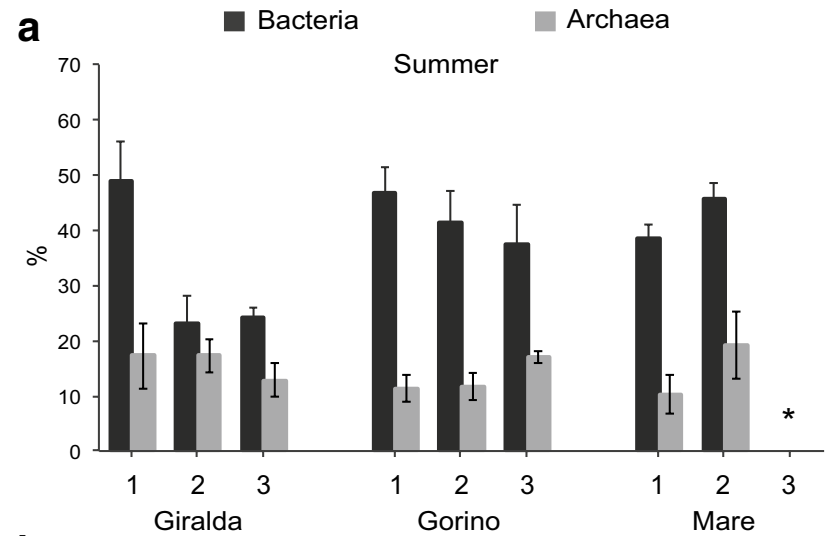

b

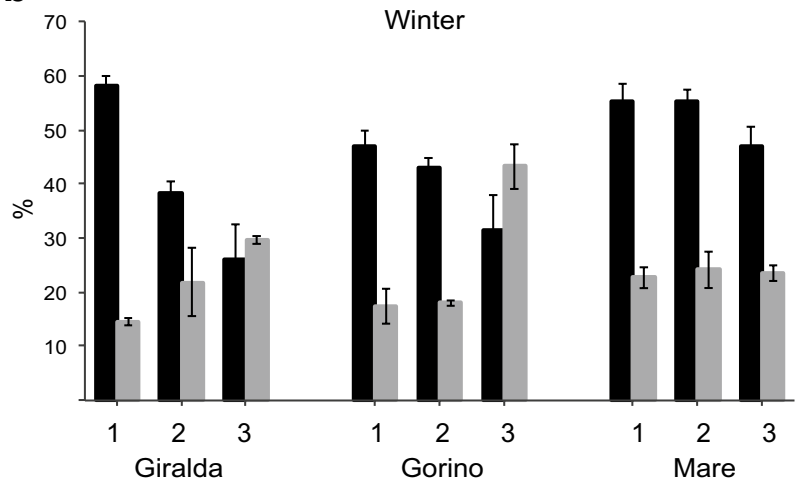

Fig. 2 Bacterial and archaeal relative abundance at Giralda, Gorino, and Mare during a summer 2011, asterisk represents not detected, and b winter 2012. The numbers 1,2 , and 3 indicate the different sediment layers. Layer $1(0-0.5 \mathrm{~cm})$, layer $2(0.5-2 \mathrm{~cm})$, and layer 3 $(2-5 \mathrm{~cm})$
Bacteria were always higher in abundance than Archaea, with bacterial cells number usually peaking at the sediment surface and decreasing with sediment depth (ANOVA, Tukey test, $P<0.01)$. Archaea showed an opposite trend with higher abundance in deeper sediment layers (ANOVA, Tukey test, $P<0.01$; Fig. 3a, b). At Giralda, both, in summer and winter, bacterial cells number strongly decreased with sediment depth (from ca. 2 to ca. 0.5 cells $\times 10^{8} \mathrm{~g}^{-1}$ ), while Archaea remained at 0.5 cells $\times 10^{8} \mathrm{~g}^{-1}$ in all layers during the summer, but increased slightly with depth in winter ( $0.3-0.7$ cells $\left.\times 10^{8} \mathrm{~g}^{-1}\right)$. At Gorino, the opposing downwards trends of Archaea and Bacteria can be observed for both seasons, although bacterial cells number are lower during winter (decreasing from 1.7 cells $\times 10^{8} \mathrm{~g}^{-1}$ to 0.7 cells $\times 10^{8} \mathrm{~g}^{-1}$ ). At Mare, bacterial cells number were especially high in summer (highest numbers across all stations; 2.5 cells $\times 10^{8} \mathrm{~g}^{-1}$ ), but without a clear downwards trend, Fig. 3a, b. The Archaea during summer at Mare showed again the trend of increasing numbers with depth, reaching highest numbers for all stations and seasons (1.0 cells $\left.\times 10^{8} \mathrm{~g}^{-1}\right)$. In winter, bacterial cells number at Mare decreased substantially (to ca. 1.0 cells $\times 10^{8} \mathrm{~g}^{-1}$ ) and again showed no depth trend. Also statistically, the bacterial abundance at Mare was significantly higher than at Gorino and Giralda in summer (ANOVA, $P<0.05$ ), and at Gorino in winter (ANOVA, $P<0.001$ ), (Fig. 3a, b).

\section{Discussion}

The transition from the continental to the marine domains determines steep gradients of the environmental parameters that, from one hand promote unique ecosystems services, and on the other side make this habitat the most vulnerable coastal system to climatic and human pressure. Sacca di Goro is recognised as an experimental field site for studying Mediterranean watershed-coastal lagoon interactions, where microbes play a major role in organic matter remineralisation and in carbon transfer to higher trophic levels [26]. However, the lack of information about microbial abundance, community composition, and diversity are the major gaps for understanding the coastal lagoon biogeochemical cycling and the role of microbes in buffering the increasing anthropogenic impact. In this study, for the first time, we described the temporal and spatial variation of bacterial and archaeal abundance in the Sacca di Goro lagoon sediments. Specifically we investigated the effects of seasonality and physico-chemical gradients, typically reported for this area [52] and here confirmed, on the abundance of Bacteria and Archaea in order to characterise the microbial baseline standing stock variability.

The FISH recovery efficiency observed here is consistent with previous reports for marine benthic habitats [31]; 
Fig. 3 Bacterial and archaeal abundance at Giralda, Gorino, and Mare during a summer 2011, asterisk represents not detected, and b winter 2012 a

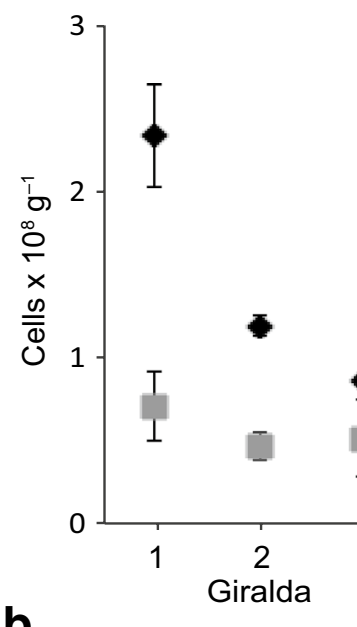

b

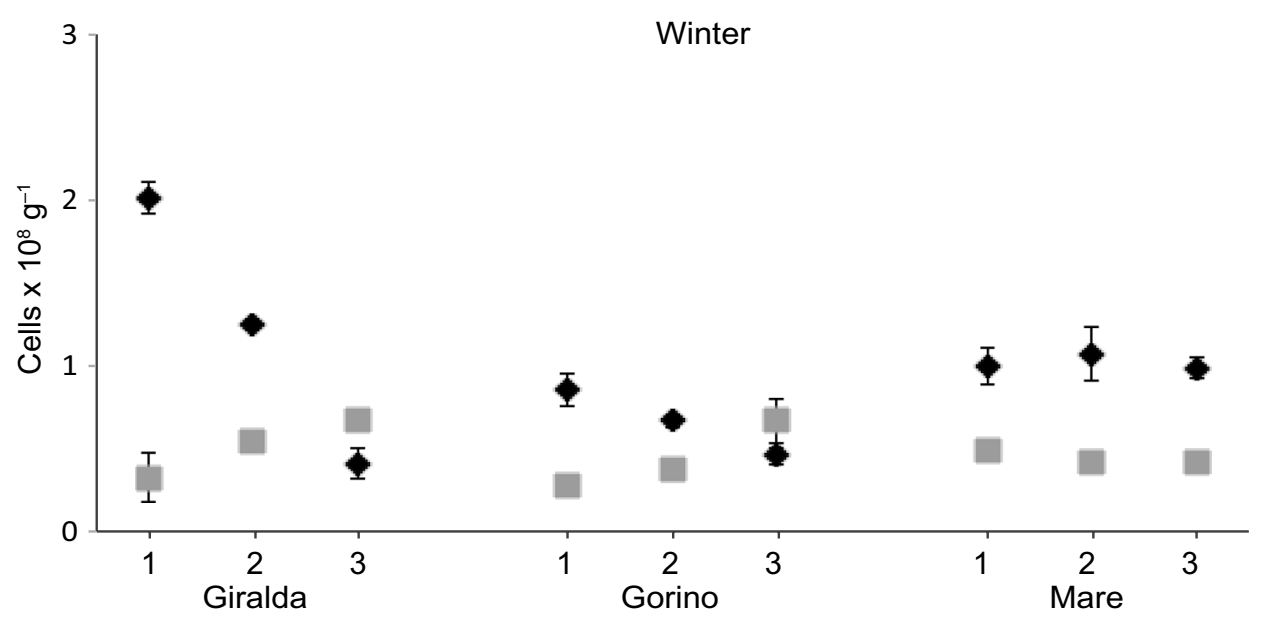

Bacteria Archaea

Summer

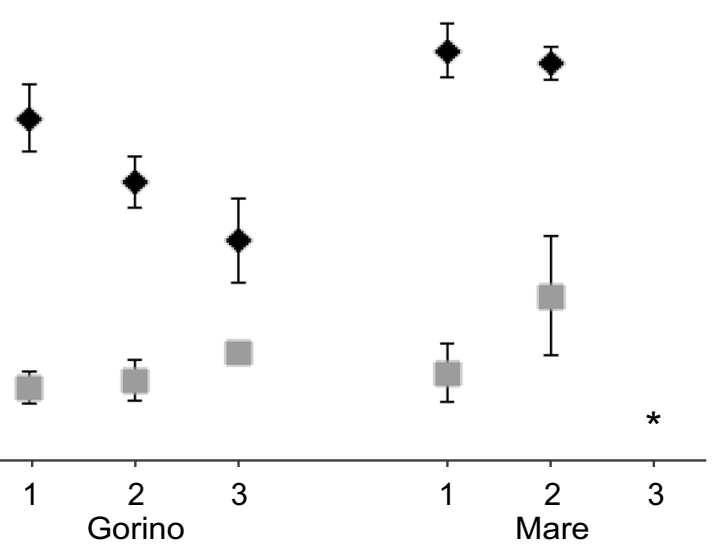


the high OM degradation rates and low hydrodynamics generated a sharp redox cline in the first top centimetres of Gorino and Giralda sediments, which may have raised the sulphate-methane-transition zone [29], then favouring archaeal communities typically described for deeper anaerobic sediment layers $[8,18,25]$. In this scenario, our findings suggest that in anoxic sediments of highly productive coastal lagoons, such as Sacca di Goro, Archaea could play a so far neglected role in carbon cycling.

The seasonality was a principal source of variability of bacterial and archaeal standing stocks (Table S1). Focussing on the data from the surface sediment layer, the variables strongly affected by seasonality and riverine incoming waters (i.e. temperature, $\mathrm{CHLA}, \mathrm{pH}$, ammonium) explained a large proportion of variance of bacterial and archaeal abundance (Fig. 4a, b). In particular, the abundance of Bacteria was mainly driven by temperature, and equally strong by CHLA, pH, and ammonium (Fig. 4a). Conversely, the abundance of Archaea was mainly driven by $\mathrm{pH}$, and secondary by temperature (Fig. 4b).

Biological activity (i.e. metabolic and chemical reaction rates) increases exponentially with temperature [11], and thus availability of thermal kinetic energy is one of the main controlling factors of benthic microbial assemblages [28]. The low temperature of lagoon water in winter reduces the microbial activity, which likely resulted in lower bacterial density. Little variation of Archaea abundance in surficial sediments observed between summer and winter suggests that they are more tolerant than Bacteria to temperature decrease. Thermal adaptation seems to be a common feature among Archaea, as they can be abundant in different low-temperature environments $[15,21,32,50]$.

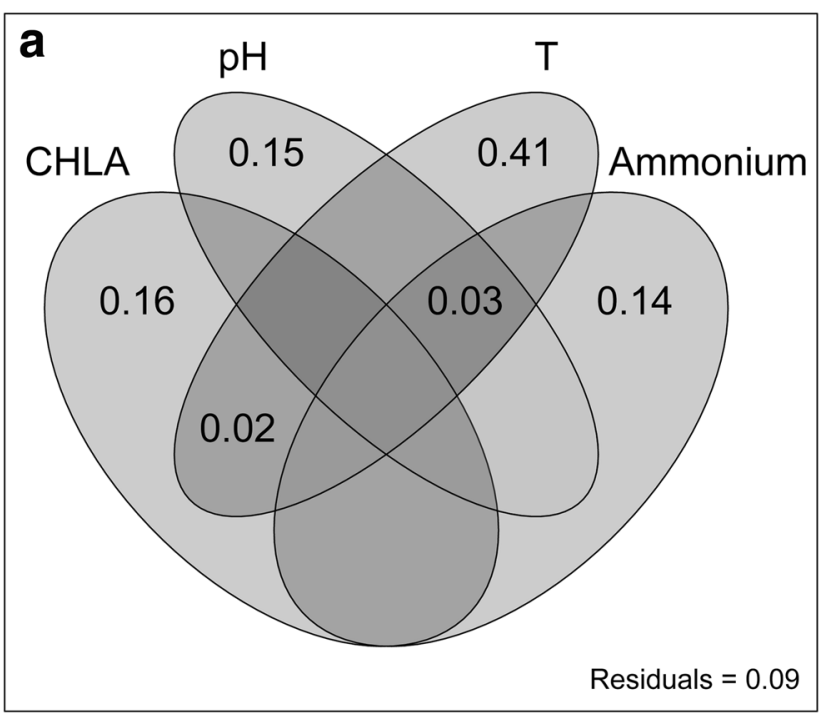

Organic carbon availability (i.e. chemical potential energy) in marine sediments is recognised as another important factor that affects the metabolism, distribution, and dynamics of benthic microorganisms [7, 15, 19]. Specifically, under trophic resource-limiting conditions, heterotrophic Bacteria and Archaea are primarily controlled by BPC and POC-flux [7, 15]. However, we could not identify a clear relationship between the amount and composition of OM and bacterial abundance. Lagoon sediments have a generally high load of organic matter in, which therefore might not have acted as a limiting factor for Sacca di Goro microbial communities. The quality, i.e. freshness of $\mathrm{OM}$ as measured in CHLA had an important role in controlling the bacterial abundance (Fig. S2a). Chlorophyll $a$ is used as a proxy of freshness because it represents the fraction of photosynthetically produced organic matter that has not been degraded, yet [40]. The fact that Archaea are not affected by the availability and composition of organic matter in superficial sediments suggests that they can use different energy source. Mostly of the Archaea found in aerobic aquatic environments are ammonium oxidisers [35], autotrophs using ammonium as electron donor and oxygen as electron acceptor in the respiratory chain. The distribution of bacterial and archaeal ammonium oxidisers in estuarine environments has been shown to depend of salinity [43], oxygen concentration [47], CHLA [1], and temperature [6]. Erguder et al. in 2009 [16] proposed specific niches for bacterial and archaeal ammonium oxidisers corresponding to varying dissolved oxygen, ammonium, $\mathrm{pH}$, phosphate, and sulphide levels. In this regard, the strong importance of $\mathrm{pH}$ explaining the Archaea variation (44\%; Fig. 4b) supports the hypothesis that Sacca di Goro surficial sediments can be

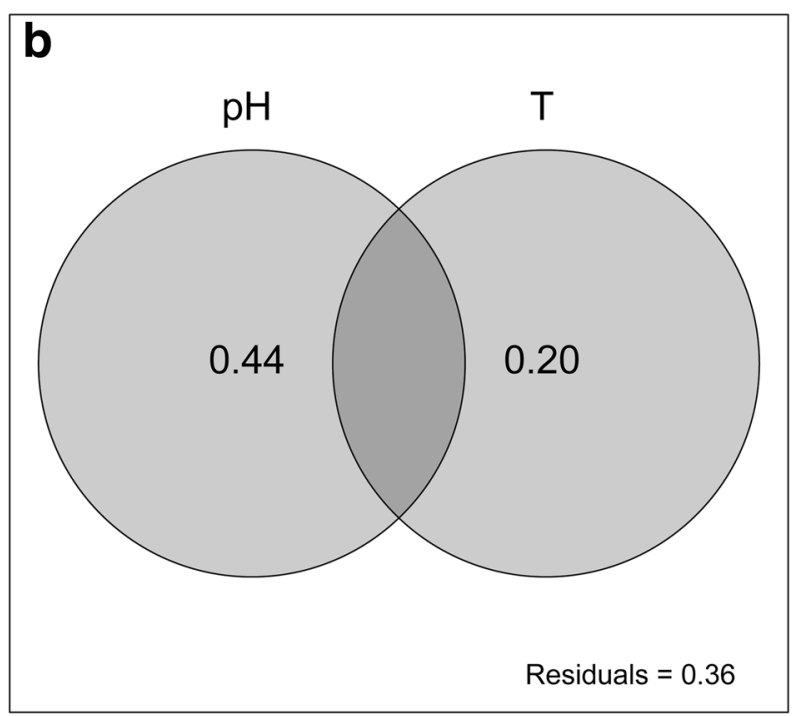

Fig. 4 Variation partitioning of variables explaining variance of $\mathbf{a}$ bacterial and $\mathbf{b}$ archaeal abundance 
dominated by $\mathrm{pH}$-sensitive archaeal functional groups, such as ammonium oxidisers.

\section{Conclusion}

The environmental parameters confirmed that Sacca di Goro lagoon is characterised by physico-chemical (i.e. $\mathrm{pH}$ and salinity) and trophic (i.e. CHLA and BPC) gradients with pronounced seasonality. We investigated the archaeal and bacterial standing stock and were able to associate changes according to certain environmental parameters. Bacterial and archaeal abundance are differentially controlled by environmental factors, suggesting that they might have a different role in aquatic biogeochemical processes. One of our main findings was that Archaea are a numerically important component of the benthic microbial assemblages in the lagoon, especially at sediment layers below a few centimetres. Also during winter, a season of decreased temperature, Archaea remain stable in abundance. We conclude that Archaea may play neglected role in $\mathrm{C}$ cycles in Mediterranean coastal lagoons, which should be elucidated in future studies for a better understanding and management of lagoon ecosystem biogeochemistry.

Acknowledgements Open access funding provided by Max Planck Society. The authors wish to thank the boat support for the sampling activities in the lagoon and the Provincia di Ferrara. We thank Verena Carvalho for the constructive criticism and for the English editing. This work was partially supported by European Science Foundation EuroDeep BIOFUN Grant CTM2007-28739-E and by a Doctoral Fellowship called Master and Back (Regional Operative Programme FSE (European Social Funding, 2007-2013)).

\section{Compliance with Ethical Standards}

Conflict of interest The authors declare that they have no conflict of interest.

Human and Animal Participants No experiments involving animals were carried out in this scientific work.

Open Access This article is distributed under the terms of the Creative Commons Attribution 4.0 International License (http://creativeco mmons.org/licenses/by/4.0/), which permits unrestricted use, distribution, and reproduction in any medium, provided you give appropriate credit to the original author(s) and the source, provide a link to the Creative Commons license, and indicate if changes were made.

\section{References}

1. Abell GCJ, Revill AT, Smith C, Bissett AP, Volkman JK, Robert SS (2010) Archaeal ammonia oxidizers and nirS-type denitrifiers dominate sediment nitrifying and denitrifying populations in a subtropical macrotidal estuary. ISME J 4:286-300

2. Amann RI, Binder BJ, Olson RJ, Chisholm SW, Devereux R, Stahl DA (1990) Combination of 16S rRNA-targeted oligonucleotide probes with flow cytometry for analyzing mixed microbial populations. Appl Environ Microbiol 56:1919-1925

3. Amann R, Fuchs BM, Behrens S (2001) The identification of microorganisms by fluorescence in situ hybridisation. Curr Opin Biotechnol 12:231-236

4. APHA (American Public Health Association) (1998) Standard methods for the examination of water and wastewaters, 20th edn. APHA, Washington DC

5. Azam F, Malfatti F (2007) Microbial structuring of marine ecosystems. Nat Rev Microbiol 5:782-791

6. Berounsky VM, Nixon SW (1993) Rates of nitrification along an estuarine gradient in Narragansett Bay. Estuaries 16:718-730

7. Bienhold C, Boetius A, Ramette A (2012) The energy-diversity relationship of complex bacterial communities in Arctic deep-sea sediments. ISME J 6:724-732

8. Boetius A, Ravenschlag K, Schubert CJ, Rickert D, Widdel F, Gieske A, Amman R, Jörgensen BB, Witte U, Pfannkuche O (2000) A marine microbial consortium apparently mediating anaerobic oxidation of methane. Nature 407:623-626

9. Borin S, Brusetti L, Daffonchio D, Delaney E, Baldi F (2009) Biodiversity of prokaryotic communities in sediments of different sub-basins of the Venice lagoon. Res Microbiol 160:307-314

10. Bower CE, Holm-Hansen T (1980) A salicylate-hypochlorite method for determining ammonia in seawater. Can J Fish Aquat Sci 37:794-798

11. Brown JH, Gillooly JF, Allen AP, Savage VM, West GB (2004) Toward a metabolic theory of ecology. Ecology 85:1771-1789

12. Daims H, Brühl A, Amann R, Schleifer KH, Wagner M (1999) The domain-specific probe EUB338 is insufficient for the detection of all Bacteria: development and evaluation of a more comprehensive probe set. Syst Appl Microbiol 22:434-444

13. Danovaro R, Pusceddu A (2007) Biodiversity and ecosystem functioning in coastal lagoons: does microbial diversity play any role? Estuar Coast Shelf Sci 75:4-12

14. Danovaro R (2010) Methods for the study of deep-sea sediments their functioning and biodiversity. Taylor \& Francis, Boca Raton

15. Danovaro R, Molari M, Corinaldesi C, Dell'Anno A (2016) Macroecological drivers of archaea and bacteria in benthic deep-sea ecosystems. Sci Adv 2:e1500961

16. Erguder TH, Boon N, Wittebolle L, Marzorati M, Verstraete W (2009) Environmental factors shaping the ecological niches of ammonia-oxidizing archaea. FEMS Microbiol Rev 33:855-869

17. Fabiano M, Danovaro R, Fraschetti S (1995) A three-year time series of elemental and biochemical composition of organic matter in subtidal sandy sediments of the Ligurian Sea (northwestern Mediterranean). Cont Shelf Res 15:1453-1469

18. Ferry JG, Lessner DJ (2008) Methanogenesis in marine sediments. Ann N Y Acad Sci 1125:147-157

19. Giovannelli D, Molari M, d'Errico G, Baldrighi E, Pala C, Manini E (2013) Large-scale distribution and activity of prokaryotes in deep-sea surface sediments of the Mediterranean Sea and the adjacent Atlantic Ocean. PLoS ONE 8:e72996

20. Ishii K, Mußmann M, MacGregor BJ, Amann R (2004) An improved fluorescence in situ hybridization protocol for the identification of Bacteria and Archaea in marine sediment. FEMS Microbiol Ecol 50:203-212

21. Karner MB, DeLong EF, Karl DM (2001) Archaeal dominance in the mesopelagic zone of the Pacific Ocean. Nature 409:507-510

22. Könneke M, Bernhard AE, José R, Walker CB, Waterbury JB, Stahl DA (2005) Isolation of an autotrophic ammonia-oxidizing marine archaeon. Nature 437:543-546 
23. Krause E, Wichels A, Giménez L, Lunau M, Schilhabel MB, Gerdts $\mathrm{G}$ (2012) Small changes in $\mathrm{pH}$ have direct effects on marine bacterial community composition: a microcosm approach. PLoS ONE 7:e47035

24. Kubo K, Lloyd KG, Biddle JF, Amann R, Teske A, Knittel K (2012) Archaea of the Miscellaneous Crenarchaeotal Group are abundant, diverse and widespread in marine sediments. ISME J 6:1949-1965

25. Lloyd KG, Schreiber L, Petersen DG, Kjeldsen KU, Lever MA, Steen AD, Stepanauskas R, Richter M, Kleindienst S, Lenk S, Schramm A (2013) Predominant archaea in marine sediments degrade detrital proteins. Nature 496:215-218

26. Manini E, Fiordelmondo C, Gambi C, Pusceddu A, Danovaro R (2003) Benthic microbial loop functioning in coastal lagoons: a comparative approach. Oceanol Acta 26:27-38

27. Manini E, Luna GM, Danovaro R (2004) Benthic bacterial response to variable estuarine water inputs. FEMS Microb Ecol 50:185-194

28. McClain CR, Allen AP, Tittensor DP, Rex MA (2012) Energetics of life on the deep seafloor. Proc Natl Acad Sci USA 109:15366-15371

29. Middelburg JJ, Levin LA (2009) Coastal hypoxia and sediment biogeochemistry. Biogeosciences 6:1273-1293

30. Molari M, Manini E (2012) Reliability of CARD-FISH procedure for enumeration of Archaea in deep-sea surficial sediments. Curr Microbiol 64:242-250

31. Molari M, Giovannelli D, d'Errico G, Manini E (2012) Factors influencing prokaryotic community structure composition in subsurface coastal sediments. Estuar Coast Shelf Sci 97:141-148

32. Molari M, Manini E, Dell'Anno A (2013) Dark inorganic carbon fixation sustains the functioning of benthic deep-sea ecosystems. Glob Biogeochem Cycles 27:212-221

33. Musat N, Werner U, Knittel K, Kolb S, Dodenhof T, Van Beusekom JE, De Beer D, Dubilier N, Amann R (2006) Microbial community structure of sandy intertidal sediments in the North Sea, Sylt-Rømø Basin, Wadden Sea. Syst Appl Microbiol 29:333-348

34. Naimi B, Hamm NAS, Groen TA, Skidmore AK, Toxopeus AG (2014) Where is positional uncertainty a problem for species distribution modelling? Ecography 37:191-203

35. Offre P, Spang A, Schleper C (2013) Archaea in biogeochemical cycles. Annu Rev Microbiol 67:437-457

36. Oksanen J, Blanchet FG, Kindt R, Legendre P, Minchin PR, O'hara RB, Simpson GL, Solymos P, Stevens MH, Wagner H, Oksanen MJ (2013) Package 'vegan'. Community ecology package, version 2(9)

37. Pernthaler A, Pernthaler J, Schattenhofer M, Amann R (2002) Identification of DNA-synthesizing bacterial cells in coastal North Sea plankton. Appl Environ Microbiol 68:5728-5736

38. Pernthaler J, Glöckner FO, Schönhuber W, Amann R (2001) Fluorescence in situ hybridization (FISH) with rRNA-targeted oligonucleotide probes. Methods Microb 30:207-226

39. Pusceddu A, Dell'Anno A, Danovaro R, Manini E, Sara G, Fabiano M (2003) Enzymatically hydrolyzable protein and carbohydrate sedimentary pools as indicators of the trophic state of detritus sink systems: a case study in a Mediterranean coastal lagoon. Estuaries 26:641-650

40. Pusceddu A, Dell'Anno A, Fabiano M, Danovaro R (2009) Quantity and bioavailability of sediment organic matter as signatures of benthic trophic status. Mar Ecol Progr Ser 375:41-52

41. R Development Core Team (2011) R: a language and environment for statistical computing. Vienna: R Foundation for Statistical Computing

42. Ribaudo C, Bartoli M, Racchetti E, Longhi D, Viaroli P (2011) Seasonal fluxes of $\mathrm{O}_{2}$, DIC and $\mathrm{CH}_{4}$ in sediments with Vallisneria spiralis: indications for radial oxygen loss. Aquat Bot 94:134-142
43. Santoro AE, Francis CA, de Sieyes NR, Boehm AB (2008) Shifts in the relative abundance of ammonia-oxidizing bacteria and archaea across physicochemical gradients in a subterranean estuary. Environ Microbiol 10:1068-1079

44. Schippers A, Neretin LN, Kallmeyer J, Ferdelman TG, Cragg BA, Parkes R, Jørgensen BB (2005) Prokaryotic cells of the deep sub-seafloor biosphere identified as living bacteria. Nature 433:861-864

45. Seyler LM, McGuinness LM, Kerkhof LJ (2014) Crenarchaeal heterotrophy in salt marsh sediments. ISME J 8:1534-1543

46. Stahl DA, Amann R (1991) Development and application of nucleic acid probes in bacterial systematics. In: Stackebrandt E, Goodfellow M (eds) Nucleic acid techniques in bacterial systematics. Wiley, Chichester, pp 205-248

47. Swan BK, Ehrhardt CJ, Reifel KM, Moreno LI, Valentine DL (2010) Archaeal and bacterial communities respond differently to environmental gradients in anoxic sediments of a California hypersaline lake, the Salton Sea. Appl Environ Microbiol 76:757-768

48. Torres-Alvarado MdR, Fernández FJ, Ramírez Vives F, Varona-Cordero F (2013) Dynamics of the methanogenic archaea in tropical estuarine sediments. Archaea. https://doi. org/10.1155/2013/582646

49. Treude T, Knittel K, Blumenberg M, Seifert R, Boetius A (2005) Subsurface microbial methanotrophic mats in the Black Sea. Appl Environ Microbiol 71:6375-6378

50. Valentine DL (2007) Adaptations to energy stress dictate the ecology and evolution of the Archaea. Nat Rev Microbiol 5:316-323

51. Viaroli P, Azzoni R, Bartoli M, Giordani G, Taje` L (2001) Evolution of the trophic conditions and dystrophic outbreaks in the Sacca di Goro lagoon (Northern Adriatic Sea). In: Faranda FM, Guglielmo L, Spezie G (eds) Structure and processes in the Mediterranean ecosystems, vol 59. Springer, Milano, pp 467-475

52. Viaroli P, Bartoli M, Azzoni R, Giordani G, Mucchino C, Naldi M, Nizzoli D, Tajé L (2005) Nutrient and iron limitation to Ulva blooms in a eutrophic coastal lagoon (Sacca di Goro, Italy). Hydrobiology 550:57-71

53. Viaroli P, Giordani G, Cattaneo E, Zaldivar JM, Murray CN (2001) Sacca di Goro Lagoon. In: Dupra V, Smith SV, Marshall Crossland JI, Crossland CJ (eds) Coastal and estuarine systems of the Mediterranean and Black Sea Regions: carbon, nitrogen and phosphorus fluxes. LOICZ reports studies, vol 19, pp 36-45

54. Viaroli P, Naldi M, Bondavalli C, Bencivelli S (1996) Growth of the seaweed Ulva rigida C. Agardh in relation to biomass densities, internal nutrient pools and external nutrient supply in the Sacca di Goro lagoon (Northern Italy). Hydrobiologia 329:93-103

55. Wallner G, Amann R, Beisker W (1993) Optimizing fluorescent in situ hybridization with rRNA-targeted oligonucleotide probes for flow cytometric identification of microorganisms. Cytom A $14: 136-143$

56. Wickham H (2009) ggplot2: elegant graphics for data analysis. Springer, New York

57. Whitman WB, Coleman DC, Wiebe WJ (1998) Prokaryotes: the unseen majority. Proc Natl Acad Sci USA 95:6578-6583

58. Zaldívar JM, Viaroli P, Newton A, De Wit R, Ibañez C, Reizopoulou S, Somma F, Razinkovas A, Basset A, Holmer M, Murray N (2008) Eutrophication in transitional waters: an overview. Transit Waters Monogr 2:1-78

59. Zilius M, Giordani G, Petkuviene J, Lubiene I, Ruginis T, Bartoli M (2015) Phosphorus mobility under short-term anoxic conditions in two shallow eutrophic coastal systems (Curonian and Sacca di Goro lagoons). Estuar Coast Shelf Sci 164:134-146 